\title{
MATERIAL AND SUBJECTIVE WELLBEING OF MALAYSIAN HOUSEHOLD: A COMPARATIVE ANALYSIS
}

\author{
Farah Shazlin Johari \\ Faculty of Business and Management \\ Universiti Teknologi MARA, Cawangan Melaka, Malaysia \\ E-mail: farahshazlin@uitm.edu.my \\ Hamidah Muhd Irpan \\ Faculty of Computer and Mathematical Sciences \\ Universiti Teknologi MARA, Cawangan Melaka, Malaysia \\ Mohamed Saladin Abdul Rasool \\ Faculty of Business and Management \\ Universiti Teknologi MARA, Cawangan Melaka, Malaysia
}

\begin{abstract}
The concept of wellbeing has attracted many researchers in multi-disciplines. Objective wellbeing particularly focuses on quality of life indicators such as material resources (material wellbeing). While, subjective wellbeing emphasizes on subjective experiences and judgments of individuals in their lives in better ways. In fact, numerous studies have shown several determinants associated with material and subjective wellbeing. To gain better understanding, the purpose of this study is to explore the impact of demographic factors, including age, gender income, education and health status on both material and subjective wellbeing among households. This cross-sectional study was conducted in the district of Alor Gajah, Melaka which had the second highest score of Malaysian Wellbeing Index 2016. By using self-administered questionnaires, the present study employed non-proportionate random sampling involving households. The findings revealed that demographic factors are associated with material and subjective wellbeing.
\end{abstract}

Keywords: Demographic, Material Wellbeing, Subjective Wellbeing, Muslim Households.

\section{INTRODUCTION}

The concept of well-being has attracted the interest of many researchers in various fields such as economics, social and psychology. Indeed, extensive literature has recognised wellbeing into two different perspectives, namely hedonic and eudaimonic (Ryan \& Deci, 2001; Disabato et al., 2016; Tov, 2018). While other researchers use the term material and subjective wellbeing. The term material wellbeing represent wellbeing based on material resources such as financial management, health, and comfort home (Popova \& Pishniak, 2017) meanwhile, satisfaction with life, social life, home environment and practicing pure value will be part of the element of subjective wellbeing (White, 2009). 
Therefore, the aims of this study was to explore the influence of demographic characteristics, including age, gender income, education and health status on material and subjective wellbeing among household in Malaysia. Specifically, comparative analysis between material and subjective wellbeing would be undertaken.

\section{LITERATURE REVIEW}

Material and subjective are two important components of wellbeing. Material wellbeing is in accordance with quality of life indicators such as material resources (e.g. income, food, and housing) and social attributes (e.g. education, health, and social networks) (OECD Malaysia Economic Survey, 2019; Diener \& Suh, 1997). Meanwhile, the subjective approach emphasizes on people's self-assessment of their lives, especially those related to life satisfaction, happiness and unhappiness (Diener \& Suh, 1997). Despite differences in their respective concepts, both material and subjective approaches are interrelated and capable of influencing each other domains.

\section{Material Wellbeing}

In general, material aspects of wellbeing are unequally distributed according to age, gender, education, class, health and income. Material wellbeing is referred to satisfaction with wide-range of economic matters including economy, taxes, basic necessities, household income, salaries and benefits, financial security and living standard (Popova \& Pishniak, 2017; Sirgy, 2018). In fact, monetary matters such as disposable income and expenditures are considered as key component in standard of living assessment (OECD 2011; Land, Michalos et al., 2012; UNDP 2014). Likewise, indicators of scarcity or basic needs are used to capture current household consumption capacity, including subjective assessment in determining whether they are financially stable or otherwise (Nolan \& Whelan, 1996). Furthermore, subjective assessment of material wellbeing by respondents can be a useful complement to more objective data as they can influence household behaviour (OECD, 2013).

Several studies revealed that there is significant influence between demographic factors such as education and gender, in which these factors can ultimately lead to persistent social inequalities in health and wellbeing (Klug, Drobnic, \& Brockmann, 2019; Popova \& Pishniak, 2017; Diener et al., 2010). Indeed, some countries differ in the degree of gender inequality (Behkouche et al., 2015), where men were expected to be advantaged over women with respect to most objective aspects of material wellbeing. In addition, socioeconomic such as income and class differences in the family are associated with differences in educational achievement (De Bortoli \& Thomson, 2010), and better health condition (Spurrier et al., 2003) which themselves are associated with variations in employment outcomes in future life (Zucchelli et al., 2010). Essentially, education attainment, qualification and market skills are also associated with social class, where they are fundamentally linked to the economic conditions of people's lives such as having economic, capital or organizational resources (Goldthorpe, 2007; Wrigth, 2009).

\section{Subjective Wellbeing}

Similarly, numerous researches discuss extensively the association between demographic factors and subjective wellbeing. Likewise, gender is often used as an indicator of subjective wellbeing (Cramm et al., 2010; Diener \& Biswas-Diener, 2002), but there are still contradictory in findings. In fact, most studies claim that women are reported slightly higher subjective wellbeing than men (Xu et al., 2019; Frey \& Stutzer, 2002; Gerdtham \& Johannesson, 2001; Hoorn, 2007; Jorgensen et al., 2010). Meanwhile, other studies have found no gender differences between women and men 
(Diener \& Scollon, 2003). In addition, some evidences suggest education has both positive and negative effects on subjective wellbeing. As education has the potential to influence people's employment, income and social status (Agrawal et al., 2010; Ross \& Willigen, 1997), the results often contribute to improving the individuals' subjective wellbeing in positive ways (Yu et al., 2019; Diener \& Scollon, 2003; Frey \& Stutzer, 2003).

Meanwhile, the findings for age and health status are more consistent with other studies. The identification of the "u-shaped" relationship between age and subjective wellbeing indicates that individuals are happier at youth and old age (Xu et al., 2019; Blanchflower \& Oswald 2008; Gerdtham \& Johannesson, 2001; Hoorn, 2007). In turn, it results in lower subjective wellbeing among middle-aged people (Steptoe et al., 2015; Xu et al., 2019). In addition, empirical evidences also consistently reported high positive relationships between health and wellbeing (Wang et al., 2015; Diener, 2002; Diener \& Scollon 2003; Dolan et al., 2008; Frey \& Stutzer, 2002; Hoorn, 2007). When an individual has a good and better health, it is definitely associated with subjective wellbeing (Xu et al., 2019). In fact, research indicates that good health may be the cause and effect of higher subjective wellbeing (Diener \& Biswas-Diener, 2002).

Besides, other studies were also conducted on the relationship between economic variables and wellbeing, indicating that subjective wellbeing associates positively with income (Wolbring et al., 2013; Chuliang, 2017; Cramm et al., 2010; Fahey et al., 2005; Keck \& Krause, 2007). However, some studies show income moderately associates with subjective wellbeing (Easterlin, 1973), while other studies indicate weak relationship between absolute income and happiness (Diener et al., 2013; Cramm et al., 2010; Diener \& Biswas-Diener, 2002; Easterlin, 2001). Individuals tend to compare their own income with those of their reference group and this comparison technically affects subjective wellbeing, resulting in a weaker relationship between income and subjective wellbeing (Easterlin, 1995).

\section{METHODOLOGY}

This quantitative research study employed data derived from a random survey using nonproportionate random sampling comprising of household heads in Alor Gajah, district with the second highest score of Malaysian Wellbeing Index 2016. 149 household head in Alor Gajah involved in this survey. A close-ended questionnaire was used to collect information about the demographic, material, and subjective wellbeing among respondents. Data for wellbeing part was collected using Likert scale of 1 to 5. Likert scale 1 represent strongly disagree while Likert 5 represent strongly agree for each item in wellbeing section. The usability of items to measure material and subjective wellbeing was validated by reliability test. Pearson correlation was used to investigate the relationship between material and subjective wellbeing while ANOVA test was done to reveal the significant differences of wellbeing according to demographic profile of respondents.

\section{FINDINGS}

Demographic profile of respondents is shown in Table 1. All respondents are married and majority of them are female (61.7\%). Age of respondents varies from 25 years old and above. Respondents from age group of 25-34 years old is $24.8 \%$, followed by 35-44 years old (29.5\%), 45-54 years old (31.5\%) and 55 years old and above (14.1\%). Respondents with age 55 years old and above are the minority in the age group. Respondents from income group of RM1500 and below are 23.5\%, followed by RM1500-RM3000 (30.9\%), RM3000-RM4500 (20.8\%) and RM4500 and above $(24.8 \%)$. Most of the respondents are degree holder and above $(42.3 \%)$ followed by respondents 
with SPM/ certificate (36.9\%) while only $8.1 \%$ of them are having education level of PMR/SRP/LCE. Majority of respondents are having number of households 5 and more (56.4\%) while only $8.7 \%$ of respondents are having at most 2 number of households. Lastly, $19.5 \%$ of the respondents are having chronic disease while the rest are healthy with no chronic disease $(80.5 \%)$.

Table 1. Demographic profile of respondents

\begin{tabular}{|c|c|c|c|}
\hline \multicolumn{2}{|c|}{ Demographic profile } & $\mathbf{N}$ & $\%$ \\
\hline \multirow[t]{2}{*}{ Gender } & Male & 57 & 38.3 \\
\hline & Female & 92 & 61.7 \\
\hline \multirow[t]{4}{*}{ Age group } & $25-34$ years & 37 & 24.8 \\
\hline & $35-44$ years & 44 & 29.5 \\
\hline & $45-54$ years & 47 & 31.5 \\
\hline & 55 years and above & 21 & 14.1 \\
\hline \multirow[t]{4}{*}{ Income } & RM1500 and below & 35 & 23.5 \\
\hline & RM1500-RM3000 & 46 & 30.9 \\
\hline & RM3000-RM4500 & 31 & 20.8 \\
\hline & RM4500 and above & 37 & 24.8 \\
\hline \multirow[t]{4}{*}{ Education } & PMR/SRP/LCE & 12 & 8.1 \\
\hline & SPM/Certificate & 55 & 36.9 \\
\hline & STPM/Diploma & 19 & 12.8 \\
\hline & Degree and above & 63 & 42.3 \\
\hline \multirow{3}{*}{$\begin{array}{l}\text { Number of } \\
\text { households }\end{array}$} & $1-2$ & 13 & 8.7 \\
\hline & $3-4$ & 52 & 34.9 \\
\hline & $5+$ & 84 & 56.4 \\
\hline \multirow[t]{2}{*}{ Chronic disease } & Yes & 29 & 19.5 \\
\hline & No & 120 & 80.5 \\
\hline Total & & 149 & 100.0 \\
\hline
\end{tabular}

Reliability of items to measure material and subjective wellbeing are shown in Table 2. Cronbach's alpha for material and subjective wellbeing are 0.88 and 0.89 respectively supports the reliability of items to measure both variables. Generally, respondents as whole satisfied with their material $(M=4.01)$ and subjective wellbeing $(M=3.97)$. Satisfaction on material wellbeing means the respondents agree that their financial is under control, have a good health to be productive at work and comfort home. Satisfaction on subjective wellbeing means the respondents are satisfied with the surrounding of the house, social life, practising pure values and achieving most goals aimed in life. Pearson correlation coefficient shows that the relationship of material and subjective wellbeing is significant and positively related.

Table 2. Reliability test result $(\mathrm{N}=149)$ 


\begin{tabular}{|c|l|c|c|c|}
\hline No & Item & Mean & $\begin{array}{c}\text { Std. } \\
\text { Deviation }\end{array}$ & $\begin{array}{c}\text { Cronbach's } \\
\text { Alpha }\end{array}$ \\
\cline { 1 - 3 } 1 & Control finances & 3.99 & 0.82 & 0.88 \\
\cline { 1 - 3 } 2 & Health enabled me to be productive at work & 4.00 & 0.75 & \\
\hline 3 & Good and comfort home & 4.05 & 0.88 & \\
\hline & Average material wellbeing & 4.01 & 0.74 & \multirow{2}{*}{0.89} \\
\cline { 1 - 3 } 1 & $\begin{array}{l}\text { Satisfied with the convenience and surrounding } \\
\text { of the house. }\end{array}$ & 3.96 & 0.92 & \\
\cline { 1 - 3 } 2 & Satisfied with social life & 3.82 & 0.91 & \\
\hline 3 & Practice pure values & 4.04 & 0.78 & \\
\hline 4 & Satisfied with life because most goals achieved & 4.07 & 0.94 & \\
\hline & Average subjective wellbeing & 3.97 & 0.77 & \\
\hline
\end{tabular}

Pearson correlation of material and subjective wellbeing $=0.64($ sig. $=0.00)$

Previous findings as mentioned above showed that all respondents are generally satisfied with their material and subjective wellbeing. Are they significantly differ by demographic profile of respondents? Results of ANOVA test in Table 3 revealed that there are significant differences of material and subjective wellbeing according to the age, income group and number of households. However, satisfaction on material wellbeing is significantly different whereas subjective wellbeing is not significantly different by gender. Material and subjective wellbeing are not significantly differed by education background and health condition whether they are having chronic disease or not. In brief, both material and subjective wellbeing are similarly significant by demographic factors except for gender.

Table 3. ANOVA results of material and subjective wellbeing by demographic profile

\begin{tabular}{|c|c|c|c|c|c|c|c|c|c|}
\hline \multirow{2}{*}{\multicolumn{2}{|c|}{ Demographic profile }} & \multicolumn{4}{|c|}{ Material Wellbeing } & \multicolumn{4}{|c|}{ Subjective Wellbeing } \\
\hline & & Mean & SD & $\mathrm{F}$ & Sig. & Mean & SD & $\mathrm{F}$ & Sig. \\
\hline \multirow[t]{2}{*}{ Gender } & Male & 3.85 & 0.70 & \multirow[t]{2}{*}{4.45} & \multirow[t]{2}{*}{$0.04 * *$} & 3.85 & 0.70 & \multirow[t]{2}{*}{1.98} & \multirow[t]{2}{*}{0.16} \\
\hline & Female & 4.11 & 0.74 & & & 4.04 & 0.80 & & \\
\hline \multirow[t]{4}{*}{ Age group } & $25-34$ years & 3.72 & 0.74 & \multirow[t]{4}{*}{5.88} & \multirow[t]{4}{*}{$0.00 * *$} & 3.65 & 0.73 & \multirow[t]{4}{*}{4.49} & \multirow[t]{4}{*}{$0.01 * *$} \\
\hline & $35-44$ years & 3.98 & 0.66 & & & 3.97 & 0.65 & & \\
\hline & $45-54$ years & 4.34 & 0.68 & & & 4.24 & 0.81 & & \\
\hline & $\begin{array}{l}55 \text { years and } \\
\text { above }\end{array}$ & 3.87 & 0.75 & & & 3.94 & 0.79 & & \\
\hline \multirow[t]{4}{*}{ Income } & $\begin{array}{l}\text { RM1500 and } \\
\text { below }\end{array}$ & 4.15 & 0.70 & \multirow[t]{4}{*}{2.42} & \multirow[t]{4}{*}{$0.07 *$} & 4.14 & 0.72 & \multirow[t]{4}{*}{2.22} & \multirow[t]{4}{*}{$0.09 *$} \\
\hline & $\begin{array}{l}\text { RM1500- } \\
\text { RM3000 }\end{array}$ & 3.83 & 0.79 & & & 3.79 & 0.82 & & \\
\hline & $\begin{array}{l}\text { RM3000- } \\
\text { RM4500 }\end{array}$ & 3.90 & 0.73 & & & 3.85 & 0.69 & & \\
\hline & $\begin{array}{c}\text { RM4500 and } \\
\text { above }\end{array}$ & 4.20 & 0.66 & & & 4.13 & 0.76 & & \\
\hline \multirow[t]{2}{*}{ Education } & PMR/SRP/LCE & 4.08 & 0.85 & \multirow[t]{2}{*}{1.31} & \multirow[t]{2}{*}{0.27} & 4.06 & 0.91 & \multirow[t]{2}{*}{1.52} & \multirow[t]{2}{*}{0.21} \\
\hline & SPM/Certificate & 4.14 & 0.77 & & & 4.13 & 0.74 & & \\
\hline
\end{tabular}




\begin{tabular}{|c|c|c|c|c|c|c|c|c|c|}
\hline & STPM/Diploma & 4.05 & 0.64 & & & 3.91 & 0.64 & & \\
\hline & $\begin{array}{l}\text { Degree and } \\
\text { above }\end{array}$ & 3.88 & 0.70 & & & 3.84 & 0.79 & & \\
\hline \multirow{3}{*}{$\begin{array}{l}\text { Number of } \\
\text { households }\end{array}$} & $1-2$ & 3.49 & 0.65 & \multirow[t]{3}{*}{20.67} & \multirow[t]{3}{*}{$0.00 * *$} & 3.48 & 0.63 & \multirow[t]{3}{*}{12.45} & \multirow[t]{3}{*}{$0.00 * *$} \\
\hline & $3-4$ & 3.66 & 0.65 & & & 3.69 & 0.68 & & \\
\hline & $5+$ & 4.31 & 0.70 & & & 4.22 & 0.74 & & \\
\hline \multirow{2}{*}{$\begin{array}{l}\text { Chronic } \\
\text { disease }\end{array}$} & Yes & 4.02 & 0.76 & \multirow[t]{2}{*}{0.01} & \multirow[t]{2}{*}{0.94} & 4.09 & 0.87 & \multirow[t]{2}{*}{0.81} & \multirow[t]{2}{*}{0.37} \\
\hline & No & 4.01 & 0.73 & & & 3.94 & 0.74 & & \\
\hline \multicolumn{2}{|r|}{ Total } & 4.01 & 0.74 & & & 3.97 & 0.77 & & \\
\hline
\end{tabular}

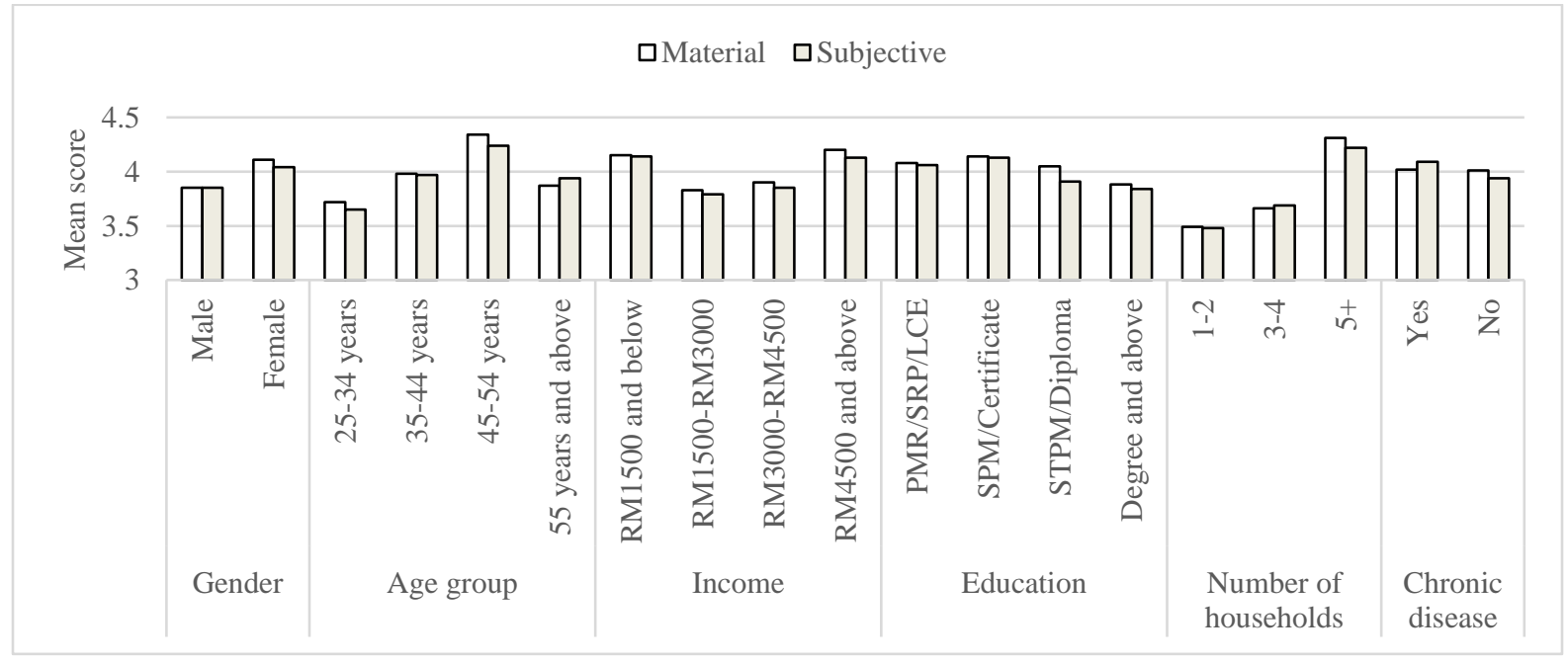

Figure 1. Mean scores of material and subjective wellbeing by demographic profile

Figure 1 shows the general trend of satisfaction of both material and subjective wellbeing according to the demographic profile. Satisfactions on both wellbeing concepts are increasing by age group and decrease after achieving 55 years old and above. Material and subjective wellbeing for respondents with income RM1500 and below, also degree and above are higher compared to respondents with income between RM1500 and RM4500. Lastly, material and subjective wellbeing increases as the number of household increase.

\section{CONCLUSION}

This cross-sectional study enhances knowledge by mobilizing the conceptualization of material and subjective wellbeing among household in Melaka. We examined the demographic characteristics including gender, age, income, education level, household number and health condition as potential indicator related to both wellbeing. Our study provides empirical evidence that most Muslim households have high level of material and subjective wellbeing. However, there are significant differences of both wellbeing concepts across demographic characteristics such as age, gender, income and number of households due to the different respondents' backgrounds. Specifically, as reported by most female, old age, lower education and higher income level significantly have higher material and subjective wellbeing. Contrary, households with limited number of households and those without chronic diseases have lower material and subjective wellbeing levels. Thus, demographic characteristics are significantly associated with both 
wellbeing. Hence, future research is recommended to further investigate the association of demographic factors with material and subjective wellbeing. Furthermore, the role of other factors besides demographic factors could also be examined in the context of household wellbeing.

\section{REFERENCES}

Agrawal, J., Philip, M., Murty, P., \& Mehrotra, S. (2010). Socio-demographic correlates of subjective sell-being in Urban India. Soc. Indic. Res., 101, 419-434.

Alatartseva, E., \& Barysheva, G. (2015). Well-being: Subjective and Objective Aspects. Procedia Social and Behavioral Sciences, 166, 36-42.

Behkouche, Y., Hausmann, R., Tyson, L., Zahidi, S., Ugarte, P., \& Ratchiva, V. (2015). The Global Gender Gap Report 2015. Geneva: World Economic Forum.

Blanchflower, D. G., \& Oswald A. J. (2008). Hypertension and happiness across nation. Journal of Health Economics, 27(2), 218-233

Bohnke, P., \& Kohler, U. (2008). Well-being and Inequality. WZB Discussion Paper, 201.

Chuliang, L. (2017). Income growth and happiness growth. Rev. Ind. Econ., 2, 5-22.

Cramm, J. M., Moller, V., \& Nieboer, A. P. (2010). Improving subjective well-being of the poor in the Eastern Cape. Journal of Health Psychology, 15(7), 1012-1019.

De Bortoli, L., \& Thomson, S. (2010). Contextual factors that influence the achievement of Australia's Indigenous students: Results from PISA 2000-2006, Camberwell: ACER Press.

Deaton, A. (1997). The Analysis of Household Surveys: A Microeconometric Approach to Development Policy. The World Bank.

Diener, E., \& Biswas-Diener, R. (2002). Will money increase subjective well-being?. Social Indicators Research, 57(2), 119-169.

Diener, E., \& Scollon, C. N. (2003). Subjective well-being is desirable, but not the sum mum bonum. Workshop on Well-Being: University of Minnesota.

Diener, E.; \& Suh, E. (1997) Measuring quality of life: Economic, social, and subjective indicators. Soc. Indic. Res., 40, 189-216.

Diener, E.; Tay, L.; \& Oishi, S. (2013). Rising income and the subjective well-being of nations. $J$. Personal. Soc. Psychol., 104, 267-276.

Diener, E.; Wirtz, D.; Tov, W.; Chu, K.P.; Choi, D.; Oishi, S.; \& Biswasdiener, R. (2010). New Well-being Measures: Short Scales to Assess Flourishing and Positive and Negative Feelings. Soc. Indic. Res., 97, 143-156. 
Disabato, D. J., Goodman, F. R., Kashdan, T. B., \& Short, J. L. (2016). Different types of wellbeing? A cross-cultural examination of hedonic and eudaimonic well-being. Psychological Assessment, 28(5), 471-482.

Dolan, P., Peasgood, T., \& White, M. (2008). Do we really know what makes us happy? A review of the economic literature on the factors associated with subjective well-being. Journal of Economic Psychology, 29, 94-122.

Easterlin, R. A. (1973). Does money buy happiness. The Public Interest, 3-10.

Easterlin, R. A. (1995). Will raising the incomes of all increase the happiness of all? Journal of Economic Behaviour and Organisation, 27, 35-47.

Easterlin, R. A (2001). Income and happiness: Towards a unified theory. The Economic Journal, $111,465-484$.

Fahey, T., Whelan, C. T., \& Maitre, B. (2005). First European quality of life survey: Income inequalities and deprivation. Luxembourg: Office for Official Publications of the European Communities.

Frey, B. S., \& Stutzer, A. (2002). What Can Economists Learn from Happiness Research? Journal of Economic Literature, 40(2), 402-435.

Frey, B. S., \& Stutzer, A. (2003). Testing Theories of Happiness. Zurich IEER Working Paper, 147.

Gerdtham, U. G., \& Johannesson, M. (2001). The relationship between happiness, health, and social economic factors: Results based on Swedish microdata. The Journal of SocioEconomics, 30(6), 553-557.

Goldthorpe, J. H. (2007). On sociology (2nd ed.) Stanford, CA: Stanford University Press.

Hoorn, A. (2007). A short introduction to subjective well-being: Its measurement, correlates and policy use.

Jorgensen, B. S., Jamieson, R. D. \& Martin, J. F. (2010). Income, sense of community and subjective well-being: combining economic and psychological variables. Journal of Economic Psychology, 31(4), 612-623.

Keck, W., \& Krause, P. (2007). How does European Union enlargement affect social cohesion? In R. J. Estes (Ed.). Advancing quality of life in a turbulent world, 3-24.

Klug, K., Drobnic, S., \& Brockmann, H. (2019). Trajectories of insecurity: Young adults' employment entry, health and well-being. Journal of Vocational Behavior, 1-16. 
Land, K. C., Michalos, A. C. et al., Eds. (2012). Handbook of social indicators and quality of life research. London, New York, Springer.

Nolan, B. \& C. T. Whelan (1996). Resources, deprivation and the measurement of poverty. Oxford, Clarendon Press.

OECD (2013). OECD guidelines on measuring subjective well-being, OECD.

OECD (2011). How's life? Measuring well-being. Paris, OECD.

OECD Malaysia Economic Survey. (2019, April 24). Retrieved from http://www.oecd.org/economy/malaysia-economic-snapshot/

Popova, D., Pishniak, A. (2017). Measuring Individual Material Well-Being Using Multidimensional Indices: An Application Using the Gender and Generation Survey for Russia. Soc Indic Res., 130, 883-910.

Ross, C.E.; \& Willigen, M.V. (1997). Education and the subjective quality of life. J. Health Soc. Behav., 38, 275-297.

Ryan, R. M., \& Deci, E. L. (2001). On happiness and human potentials: A review of research on hedonic and eudaimonic well-being. Annual Review of Psychology, 52, 141-166.

Sirgy, M. J. (2018). The psychology of material well-being. Applied Research in Quality of Life, 13(2), 273-301.

Spurrier N. J., Sawyer, M. G., Clark, J. J., \& Baghurst, P. (2003). Socio-economic differentials in the health-related quality of life of Australian children: results of a national study. Australian and New Zealand. Journal of Public Health, 27, 27-33.

Steptoe, A., Deaton, A., \& Stone, A.A. (2015). Subjective wellbeing, health, and ageing. Lancet, $385,640-648$.

Tov, W. (2018). Well-being concepts and components. In E. Diener, S. Oishi, \& L. Tay (Eds.), Handbook of well-being. Salt Lake City, UT: DEF Publishers.

UNDP. (2014). Human Development Report 2014. Sustaining human progress: Reducing vulnerabilities and building resilience. New York, NY, UNDP.

Voukelatou, V., Gabrielli, L., Miliou, I., Cresci, S., Sharma, R., Tesconi, M., \& Pappalardo, L.(2020). Measuring objective and subjective well-being: dimensions and data sources. International Journal of Data Science and Analytics.

Wang, X., Jia, X., Zhu, M., Chen, J. (2015). Linking health states to subjective well-being: An empirical study of 5854 rural residents in China. Public Health, 129, 655-666. 
Western, M., \& Tomaszewski, W. (2016). Subjective Wellbeing, Objective Wellbeing and Inequality in Australia. PloS one, 11(10), e0163345.

White, S. (2009). Analyzing wellbeing: A framework for development practice. Development in Practice, 20.

Wolbring, T.; Keuschnigg, M.; \& Negele, E. (2013). Needs, comparisons, and adaptation: The importance of relative income for life satisfaction. Eur. Sociol. Rev., 29, 86-104.

Wright, E. O. (2009). Understanding class: towards an integrated analytic account, New Left Review, 101-116.

Xu, W., Sun, H., Zhu, B., Bai, W., Yu, X., Duan R., Kou, C. \& Li, W. (2019). Analysis of factors affecting the high subjective well-being of Chinese residents based on the 2014 china family panel study. International Journal of Environment Research and Public Health, $16,2566-2579$.

Yu, K., Zhang, Y., Zou H., \& Wang C. (2019). Absolute income, income inequality and the subjective well-being of migrant workers in China: toward an understanding of the relationship and its psychological mechanisms. International Journal of Environment Research and Public Health, 16, 2597-2624.

Zucchelli, E., Jones, A., Rice, N., \& Harris, A. (2010). The effects of health shocks on labour market exits: Evidence from the HILDA survey. Australian Journal of Labour Economics, 13(2), 191-218.

\section{Copyrights}

Copyright for this article is retained by the author(s), with first publication rights granted to the journal. This is an open-access article distributed under the terms and conditions of the Creative Commons Attribution license (https://creativecommons.org/licenses/by/4.0) 